\title{
Trigeminal Herpes Zoster: Case Report
}

\author{
Herpes Zoster Trigeminal: Relato de Caso
}

Herpes zóster con afectación del nervio trigémino: reporte de caso

\author{
Marcos André KILLNER \\ DDS, Private Practice \\ Universidade Tuiuti do Paraná, 82010-330 Curitiba - PR, Brazil \\ Fernanda Noguez SUM \\ DDS, Master Student of Stomatology \\ Pontifícia Universidade Católica do Paraná, 80215-901 Curitiba- PR, Brazil \\ https://orcid.org/0000-0001-8369-9993 \\ Rafaela Savio MELZER \\ DDS, Master Student of Stomatology \\ Pontifícia Universidade Católica do Paraná, 80215-901 Curitiba - PR, Brazil \\ https://orcid.org/0000-0002-8715-4162 \\ Cintia Mussi MILANI \\ DDS, PhD, Professor of Oral Surgery and Stomatology \\ Universidade Tuiuti do Paraná, 82010-330 Curitiba - PR, Brasil \\ https://orcid.org/0000-0002-8101-2067
}

\begin{abstract}
Herpes Zoster is an acute, self-limiting, viral infection caused by the reactivation of the Varicella Zoster Virus (VZV) that remains latent in the dorsal root ganglion. It commonly affects the older people and immunocompromised individuals. Diabetes patients present an increased risk for Herpes Zoster due to their impaired cell-mediated immunity. Clinically it manifests with tingling, pruritus and painful vesicular eruptions along the affected nerve. The most commonly affected dermatomes are the thoracic and lumbar; trigeminal nerve can be involved and the ophtalmic nerve is the mostly affected. The diagnosis is based on clinical examination and laboratory confirmation. Treatment consists of antiviral therapy and is indicated to reduce acute pain symptoms, limit the spread and duration of the lesions, and prevent complications. The objective of the present study was to present a case report of Herpes Zoster involving the first and second division of the trigeminal nerve, in a 55 year old, male, diabetes patient.
\end{abstract}

Descriptors: Herpes Zoster; Trigeminal Nerve; Exanthema.

Resumo

O Herpes Zoster é infecção viral aguda, autolimitante, causada pela reativação do vírus Varicela Zoster (VZV), o qual se mantém latente nos gânglios da raiz dorsal. Afeta principalmente pessoas idosas e imunossuprimidas. Pacientes diabéticos apresentam um risco maior para o desenvolvimento do Herpes Zoster devido a sua imunidade celular prejudicada. Clinicamente a doença se manifesta com formigamento, prurido e erupção cutânea vesicular dolorosa ao longo do nervo afetado. Os dermátomos mais comumente afetados são o torácico e lombar; o nervo trigêmeo pode ser afetado, sendo mais comum o envolvimento do nervo oftálmico. O diagnóstico é baseado no exame clínico, com confirmação laboratorial. O tratamento consiste em terapia antiviral a qual reduz os sintomas agudos de dor, limita a propagação e duração das lesões e previne complicações. O objetivo do presente estudo foi apresentar um relato de caso de Herpes Zoster envolvendo a primeira e segunda divisão do nervo trigêmeo, em um paciente do gênero masculino, diabético, de 55 anos.

Descritores: Herpes Zoster; Nervo Trigêmeo; Exantema.

\section{Resumen}

El herpes zoster es una infección viral aguda y autolimitada causada por la reactivación del virus varicela zoster (VVZ), que permanece latente en los ganglios de la raíz dorsal. Afecta principalmente a personas mayores e inmunodeprimidas. Los pacientes diabéticos tienen un mayor riesgo de desarrollar Herpes Zoster debido a su inmunidad celular deteriorada. Clínicamente, la enfermedad se manifiesta con hormigueo, picazón y erupción vesicular dolorosa a lo largo del nervio afectado. Los dermatomas más comúnmente afectados son los torácicos y lumbares; el nervio trigémino puede verse afectado, y la afectación del nervio oftálmico es más común. El diagnóstico se basa en el examen clínico, con confirmación de laboratorio. El tratamiento consiste en una terapia antiviral que reduce los síntomas de dolor agudo, limita la propagación y la duración de las lesiones y previene complicaciones. El objetivo del presente estudio fue presentar un informe de caso de Herpes Zoster que involucra la primera y segunda división del nervio trigémino, en un paciente masculino, diabético, de 55 años.

Descriptores: Herpes Zoster; Nervio Trigémino; Exantema.

INTRODUCTION

Varicella-zoster (VZV) is a virus that belongs to the Herpesvirus family, which can cause two different clinical infections: a primary infection, varicella and secondary or recurrent, or herpes zoster $(\mathrm{HZ})^{1,2}$. After chickenpox is resolved, the virus remains latent in the dorsal root ganglia, and may, at some point, reactivate and trigger herpes zoster ${ }^{2-4}$.

Little is known about the mechanisms that explain the preservation of latency and subsequent reactivation of the virus, which can occur spontaneously or, in most cases, when the host's defenses are compromised; increasing age, physical trauma, psychological stress, radiation therapy, diabetes and conditions associated with immunosuppression, such as lymphoma, steroid therapies and AIDS are predisposing factors for reactivation of $\mathrm{VZV}^{3,5,6}$.

$\mathrm{HZ}$ usually affects individuals over the age of fifty, with no gender predilection ${ }^{6,7}$. Unvaccinated people who live to 85 years of age have a $50 \%$ higher risk of developing $\mathrm{HZ}$ and up to $3 \%$ need hospitalization ${ }^{8}$.

The typical clinical manifestation of $\mathrm{HZ}$ includes several days of itching, tingling and burning, followed by a painful vesicular rash along the course of the affected nerve ${ }^{5,6,9,10}$. The vesicles become cloudy, dry and form crusts after 1 or 2 weeks, and it may take up to 4 
weeks or more until the skin gets recovered ${ }^{1}$. Most $\mathrm{HZ}$ infections involve thoracic and lumbar dermatomes; approximately $13 \%$ of patients have infections involving the trigeminal nerve ${ }^{11}$. When involved, lesions may appear on the face, mouth, eyes or tongue $6,7,10,11$.

The aim of the present study was to present a case of herpes zoster affecting the first and second division of the trigeminal nerve, in a male, diabetic, 55-year-old patient.

\section{CLINICAL CASE}

A 55-year-old male patient went to a stomatologist's office, complaining of pain in the anterior upper gum due to the presence of ulcers that had appeared two weeks before that day. The anamnesis revealed that the patient was diabetic and had congestive heart failure.

In the extraoral physical exam, crusts were observed near the left nose wing, nasolabial groove and, in a lesser extent, in the upper labial region on the left side; according to the patient, the lesions had appeared at the same time as the gums lesion, initially appearing as vesicles that ruptured, forming the crusts (Figure 1). The patient claimed to have experienced burning and itching in the area, before the appearance of the vesicles, but no longer had any symptoms associated with them; however, he reported loss of cutaneous sensitivity from the frontal region of the left nose wing, burning eyes and blurred vision of the affected side.

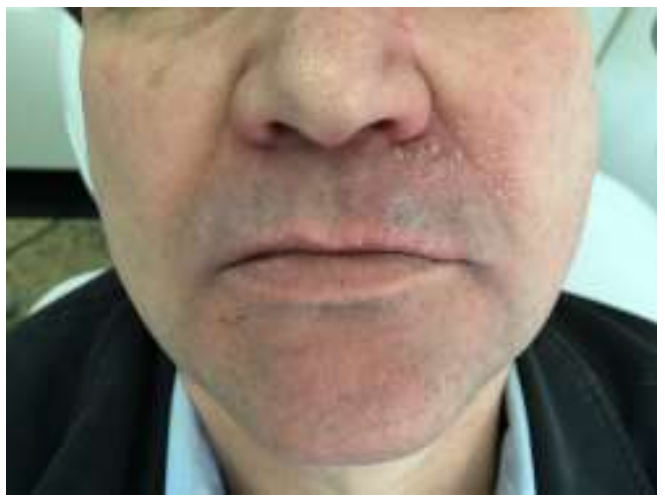

Figure 1: Facial aspect showing crusts in the nose wing and upper left lip.

The intraoral exam revealed ulcers in the gum's region of elements 21 and 22, with local bone exposure (Figure 2). After the pulp vitality test, both responded positively. Based on the patient's report and the clinical characteristics of facial and intraoral lesions, the hypothetical diagnosis of trigeminal herpes zoster was raised. DNA testing for the diagnosis of varicella zoster virus was requested and the patient was referred to an infectologist and ophthalmologist. To relieve the painful symptoms associated with the intraoral lesion, a mouthwash was prescribed with a dexamethasone elixir, 4 times a day, for 5 days.

The patient returned only 30 days later, with a DNA test confirming the diagnosis of herpes zoster. There was an improvement in facial crusts and there was a decrease in gingival lesion, which no longer caused pain to the patient. The patient did not have an ophthalmologic complaint, but the absence of skin sensitivity persisted. The patient reported using Valaciclovir 500mg (1g 12/12h) for 3 weeks, as prescribed by the infectologist.

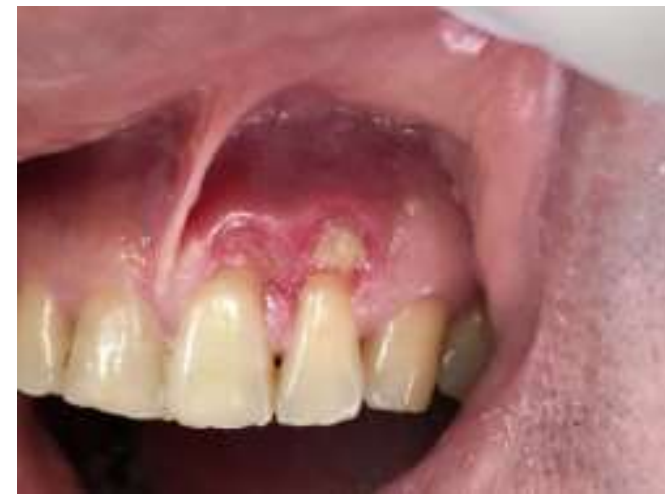

Figure 2: Ulceration area with bone exposure, in the gum region of elements 21 and 22.

In the 60-day follow-up consult, there were no more facial scabs and facial skin sensitivity was already normalized. The intraoral bone exposure, despite being less, was still present (Figure 3). The patient reported that, 3 days earlier, asymptomatic red papules had appeared on his arms and legs and that the infectious disease specialist was carrying out a series of tests to search for any autoimmune disease; a biopsy of the skin lesions was already scheduled.

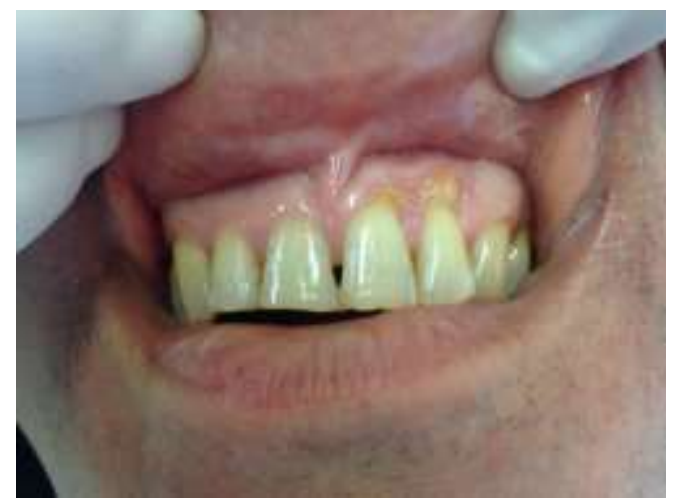

Figure 3: Intraoral clinical aspect 60 days later, showing slight improvement of the lesion, but with persistent bone exposure.

There were a series of consecutive absences to consultations, losing the follow-up of the case. More than 1 year later, the patient returned and reported that at the time the infectologist had diagnosed sarcoidosis and that, since then, he had been following up. The patient also reported that the complete healing of the oral lesion had occurred approximately 1 
month after his last dental appointment. An intraoral exam revealed normal gums, with complete local healing and no other changes in normality (Figure 4).

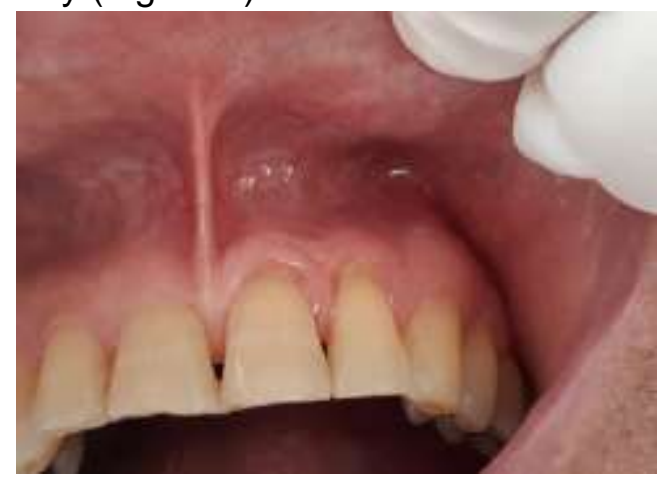

Figure 4: Intraoral aspect showing complete healing of the lesion. DISCUSSION

$\mathrm{HZ}$ is a characteristic disease of the elderly; individuals over 60 are 8 to 10 times more likely to develop the disease than those under $60^{5}$. In addition to age, people in an immunosuppressive state, such as bone marrow transplant recipients and HIV-positive patients are also at risk ${ }^{2,5,10}$. Some authors recommend that, regardless of the concomitant presence of other risk factors, all patients with herpes zoster should be tested for $\mathrm{HIV}^{3}$.

It is well established in the literature that patients with diabetes mellitus are at higher risk for the incidence of $\mathrm{HZ}$ and post-herpetic neuralgia ${ }^{12-14}$. Diabetes can affect cellular immunity by different mechanisms, facilitating the reactivation of the varicella-zoster virus ${ }^{13,14}$. A study of 330 cases of $\mathrm{HZ}$ involving cranial nerves, revealed that $25 \%$ of patients had comorbidities, the most common being diabetes $(14.8 \%)$ and malignant tumors (5.2\%); autoimmune diseases were seen in $3 \%$ of patients ${ }^{10}$. Sarcoidosis is an autoimmune, multisystemic disease, characterized by the formation of non-caseating granulomas in the affected organs. Cases of post-herpes zoster sarcoidosis have already been reported ${ }^{15,16}$. In the present case, the diagnosis of sarcoidosis was established at the time of the appearance of skin lesions in legs and arms, after herpes zoster.

Among the cranial nerves involved by $\mathrm{HZ}$ infection, the trigeminal nerve is the most affected, with the ophthalmic branch being the most commonly involved ${ }^{2,10}$. The facial and vestibule-cochlear nerves are, respectively, the second and third cranial nerves most affected. ${ }^{10}$

The clinical characteristics of patients with $\mathrm{HZ}$ can evolve in three stages: prodromal, active and chronic ${ }^{1,2,11}$. In the first, symptoms such as pain, tingling and itching of the skin, on the distribution of the affected nerve, usually precede the rash, present in the active stage, for a few hours or several days ${ }^{2}$. During this period, if the branches of the trigeminal nerve are affected, tooth pain and pulp necrosis may occur, with significant diagnostic difficulties ${ }^{3,4,7}$. $\mathrm{HZ}$ should always be considered in the differential diagnosis of patients with atypical tooth pain ${ }^{4}$. A retrospective study with 152 cases of zoster in the head region, with 100 in the trigeminal nerve, highlighted the professionals' difficulty in making an adequate diagnosis of the disease in this prodromic phase; the authors emphasized that pain is moderate to severe, unilateral, often prevents the patient from sleeping and has never been experienced by patients ${ }^{7}$.

The active stage is characterized by the appearance of the rash that evolves from erythematous papules and edema to vesicles, in 12 to 24 hours. These progress to pustules, within one to seven days, which dry and form crusts, being exfoliated over a few weeks ${ }^{2,6}$. In the oral cavity, clinical signs appear when the maxillary or mandibular nerve is affected and are characterized, in general, by vesicles over an erythematous area, which quickly ulcerate, being covered by a whitish pseudo membrane ${ }^{2}$. The lesions can involve mobile and keratinized mucosa, usually extend to the midline and often present together the skin involvement over the affected quadrant ${ }^{1}$. Rare cases of root resorption, tooth exfoliation and osteonecrosis have been reported ${ }^{2,17}$. Some people may experience typical $\mathrm{HZ}$ pain without a cutaneous manifestation, a condition called zoster sine herpete, which is difficult to diagnose and can lead to unnecessary exams and procedures ${ }^{5,8}$.

The chronic stage, also called postherpetic neuralgia, is characterized by continuous pain that persists after the healing of skin lesions and lasts for more than 4 to 6 weeks $s^{5,9,11}$. The risk of post-herpetic neuralgia increases with age and approximately half of patients over 60 years of age develop it, with immunosuppressed being the most susceptible ${ }^{5}$.

The diagnosis of $\mathrm{HZ}$ is based on clinical examination, with laboratory confirmation ${ }^{6}$. The definitive test of $\mathrm{HZ}$ requires the detection of viral antigens using direct fluorescent antibodies or polymerase chain reaction $(\mathrm{PCR})^{6,8}$.

$\mathrm{HZ}$ is generally a self-limiting condition, with complete resolution, and its treatment is indicated to reduce acute symptoms of pain and malaise, limit the spread and duration of skin lesions and prevent complications. Antiviral therapy is recommended, with acyclovir $(800 \mathrm{mg}$ orally 5 times daily for 10 days) or famiclovir (500 mg orally 3 times daily for 7 days) or 
valacyclovir (1000 g orally 3 times daily) day for 7 days), within 72 hours after the onset of symptoms $^{3,5,9}$. Co-administration of corticosteroids can be considered for pain reduction ${ }^{3,6}$.

Although post-herpetic neuralgia is the most common complication of $\mathrm{HZ}$, other complications include meningoencephalitis, Guillain-Barré syndrome, Ramsay-Hunt syndrome, vasculitis, optic neuritis, and motor disorders ${ }^{5,11}$. Some authors also cite bacterial superinfection of the crusts by Staphylococcus aureus and Streptococcus pyogenes, scars and hyperpigmentation as a common complication ${ }^{3}$.

The vaccine with the attenuated varicella-zoster virus reduces the incidence of $\mathrm{HZ}$ by more than half and the occurrence of post-herpetic neuralgia by $2 / 3$, being recommended for patients over 60 years of age $^{5}$.

\section{CONCLUSION}

Despite being a self-limiting disease, $\mathrm{HZ}$ can cause severe pain and lead to serious complications. The dentist must be aware of the signs and symptoms of this disease, making an early diagnosis, referring the patient for immediate treatment and, thus, ensuring a good prognosis.

\section{REFERENCES}

1. Shah S, Singaraju S, Einstein A, Sharma A. Herpes zoster: A clinicocyto pathological insight. J Oral Maxillofac Pathol 2016; 20(3): 547-48.

2. Kaur R, Rani P, Malhotra D, Kaur R, Dass PK. A rare case report and appraisal of the literature on spontaneous tooth exfoliation associated with trigeminal herpes zoster. Oral Maxillofac Surg, 2016;20(3):331-36.

3. Bhandage S., Kurki M., Hosur V., Sukhija P., Bajoria A. A little-known relationship between immune recovery syndrome and herpes zoster. J Korean Assoc Oral Maxillofac Surg 2016; 42(3):169-72.

4. Brooks JK, Rostami AM, McCorckle D, Benesh SI. Trigeminal herpes zoster and Ramsay Hunt syndrome in an elderly adult: Presentation with prodromal toothache. Gerodontology. 2018; 35:276-78.

5. Steiner I, Benninger F. Manifestations of herpes virus infections in the nervous system. Neurol Clin. 2018;36:725-38

6. Francis M, Subramanian K, Sankarp SL, Potluri VLA, Prabakaran A. Herpes zoster with post herpetic neuralgia involving the right maxillary branch of trigeminal nerve: a case report and review of literature. J Clin Diagn Res. 2017; 11(1):ZD40-42.
7. Lee HL, Yeo M, Choi GH, Lee JY, Kim JS, Shin DI et al. Clinical characteristics of headache or facial pain prior to the development of acute herpes zoster of the head. Clin. Neurol. Neurosurg. 2017;152:90-4.

8. Cohen Jl. Herpes zoster. N Engl J Med 2013; 369(3):255-63.

9. Christoforou J. Neuropathic orofacial pain. Dent Clin N Am 2018; 62:565-84

10. Tsau PW , Liao MF, Hsu JJ, Hsu HC, Peng CH, Lin YC et al. Clinical Presentations and Outcome Studies of Cranial Nerve Involvement in Herpes Zoster Infection: A Retrospective Single-Center Analysis. J. Clin. Med. 2020; 9:946

11. Ganesan V, Bandyopadhyay D, Kar SS, Choudhry C, Choudhary V. Herpes zoster infection involving mandibular Division of trigeminal nerve and ramsay hunt syndrome with meningitis in na immunocompetent patient: a rare association. J Clin. Diagn. Res. 2016; 10(6):5-7.

12. Suaya JA, Chen S, Li Q, Burstin SJ, Levin MJ. Incidence of herpes zoster and persistent post zoster pain in adults with or without diabetes in the United States. Open Forum Infect Dis. 2014;1(2):1-11.

13. Aldaz P, Díaz JA, Loayssa JR, Dronda MJ, Osacáriz M, Castilla J. Herpes zoster incidence in diabetic patients. An Sist Sanit Navar. 2013; 36(1):57-62.

14. Chen HH, Lin IC, Chen HJ, Yeh SY, Kao H. Association of herpes zoster type 1 diabetes mellitus. Plos One. 2016;11(5):155-75

15. Miura T, Yamamoto T. Post-herpes zoster sarcoidosis. J Dermatol. 2014;41:458-59.

16. Yamauchi $K$, Oiso N, Iwanaga $T$, Tatsumi $Y$, Matsumura I, Thoda $Y$ et al. Post-herpes zoster sarcoidosis as a recurrence. J Dermatol 2018;45(6)1-2

17. Mendieta C, Miranda J, Brunet LI, Gargallo J, Berlini L. Alveolar bone necrosis and tooth exfoliation following herpes zoster infection: a review of the literature and case report. J Periodontol. 2005:76(1):148-53.

\section{CONFLICTS OF INTERESTS}

The authors declare no conflicts of interests.

\section{CORRESPONDING AUTHOR}

\section{Cintia Mussi Milani}

Av. Pedro Viriato Parigot de Souza, 276

80740-050 Curitiba-PR, Brazil

E-mail: cintiammilani@hotmail.com 